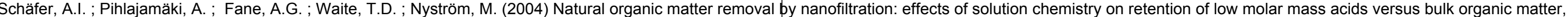

\section{Natural Organic Matter Removal by Nanofiltration: Effects of Solution Chemistry on Retention of Low Molecular Mass Acids versus Bulk Organic Matter}

A.I. Schäfer ${ }^{1 *}$, A. Pihlajamäki², A.G Fane ${ }^{3}$, T.D. Waite ${ }^{4}$, M. Nyström²

Environmental Engineering, University of Wollongong, NSW 2522, Australia

2 Laboratory of Membrane Technology and Technical Polymer Chemistry, Lappeenranta University of Technology, P.O.Box 20, F IN 53851, Lappeeranta, Finland

UNESCO Centre for Membrane Science and Technology, Chemical Engineering, University of New South Wales, Sydney, NSW 2052, Australia

4 Civil and Environmental Engineering, University of New South Wales, Sydney, NSW 2052, Australia

* to whom correspondence should be addressed (Schaefer@uow.edu.au, fax +61-2- 4221 3238, ph $+61-2-42213385)$

\section{ABSTRACT}

The main emphasis of this study is the difference in behaviour between those two organic types. Stirred cell experiments were used to investigate charge and size effects in the rejection behaviour of bulk natural organics as well as low molecular mass (LMM) acids by nanofiltration membranes.

To distinguish between size and charge effects thorough characterisation of membrane, natural organics and ionic environment was carried out Membrane zeta potential was determined as a function of the ionic envionment and the intinsic membrane jection was mesured with dextan, ion of the ionic environment and the intinsic

The behaviour of three thin film composite (TFC) and one cellulose acetate (CA) membranes was studied as a function of solution chemistry $(\mathrm{pH}$, ionic composition and strength, calcium concentration, and organic type). Rejections of $\mathrm{DOC}, \mathrm{UV}_{254 \mathrm{~nm}}$, as well as the cations calcium and sodium were measured. Natural organics in selected feed and permeate samples were also characterised using liquid chromatography organic carbon detection (LC-OCD) which allows the characterisation of the organic fractions in the low concentration permeates and hence give insight into the rejection of low molecular mass (LMM) organics. The retention of such LMM compounds is important due to their impact on the microbiological regrowth potential of the product water

The results emphasised that charge and size are both important for cations and low molecular mass acids. While the bulk of the natural organics are retained due to size exclusion that is independent on solution chemistry for the membranes investigated, the retention of IMM acids follows differen mechanisms. The analysis of oranic fraction in the permeates showed that the rejection of molecular mass acids is strongly $\mathrm{pH}$, and thus charge, dependent while this effect of solution chemistry on the LMM acids was masked when only bulk organic rejection was measured.

\section{KEYWORDS}

Membrane zeta potential, Nanofiltration, Natural organic matter, Organic separation, Water treatment. 


\section{INTRODUCTION}

Nanofiltration (NF) has become a popular method in water treatment for removal of dissolved organic carbon (DOC) or multivalent ions [1-3]. The rejection of organics in water treatment is important because atomatic compounds are known to form dinfection by produst $[4,5]$, and the smaller more aliphatic compounds ate responsible for mictobiological regrowh [6]. This leads microbiological disease for the consumer, respectively.

NF is a process in between ultrafiltration (UF) and reverse osmosis (RO), with a lower operating pressure than RO and a higher rejection than UF. NF membranes generally have a relatively high charge and 'pores' in the order of about one nm [7]. Consequently both, charge effects and sieving mechanisms may influence the rejection behaviour of solutes in NF, especially in the case of LMM organic fractions in small concentration ranges [8].

Generally it is believed that natural organics are retained due to size effects (sieving) [9], while a combination of charge and hydrated ion size is responsible for the typically high selectivity between mono- and multivalent ions that characterises NF. Very little is known about the retention of the LMM organic fractions.

In this study greater attention is given to the retention mechanisms and specifically effects of charge on organics removal than previously reported with a specific emphasis on the permeate organic fraction (such as low molecular mass (LMM) acids). This involves the thorough characterisation of the membranes (such as the determination of membrane zeta potential in various electrolyte solutions) and the characterisation of the natural organics retained and permeated.

\section{BACKGROUND}

\section{$2.1 \quad$ Natural Organic Characteristics}

A natural water often contains natural organic matter (NOM, divided into hydrophobic (humic) and hydrophilic compounds), mono- and multivalent ions, low molecular mass (LMM) organics, microorganisms, mixed complexes and inorganic colloids [10]. While the NOM characteristics are source specific, in general NOM components, such as humic substances, are negatively charged in the normal $\mathrm{pH}$ range due to the dissociation of carboxylic (and phenolic) functional groups. The organics are amphipathic in nature, i.e. contain both hydrophobic and hydrophilic moieties [11]. Size and structure of the molecules varies with solution $\mathrm{pH}$ and ionic strength, molecules are more linear when the intermolecular charge repulsion is high (low ionic strength (I) and high $\mathrm{pH}$ ) and more spherocolloidal at high I and low pH [12].

\subsection{Membrane Zeta Potential}

NF membranes are usually quite hydrophilic and chemically modified to have a relatively high charge compared to other membranes. The small pore size of NF membranes precludes measurement by transmembrane streaming potential in pores due to double layer effects and salt retention. However streaming potential analysis of the surface in a thin channel device has been established [13-15]. For example Peeters et al. [16] studied NF rejection mechanisms using thin channel streaming potential measurements with salt solutions and organics. The effect of size exclusion and zeta potential could be distinguished with this method. With different salts the membranes displayed distinct differences in measured streaming and zeta potentials and this was found to influence salt retention: he high measured stran zeta potential, the higher the retention [17].

\subsection{Nanofiltration Rejection Behaviou}

The rejection behaviour of NF membranes for ionic species is relatively well understood. Typically these membranes have high rejection for multivalent ions due to charge interactions with the 3 membrane and size exclusion of the hydrated ions. Monovalent ions tend to have lower rejections unless they are retained to maintain charge neutrality with multivalent counter ions. Thus for pure sal solutions the extended Nernst-Planck equation has been used successfully to explain rejection.

A decrease in ionic rejection is often observed with increase in ion concentration [18], presumably due to charge shielding which reduces the charge rejection mechanism. Changes in $\mathrm{pH}$ can play a role as the membrane charge tends to become more negative as $\mathrm{pH}$ increases for many common NF membranes. In addition solute speciation can alter the ionic content and change the rejection. For example, In aldit s. [18] showed for the car example, 作 monovate to divalent $\mathrm{CO}_{3}{ }^{2-}$ predominance (a higher membrane surface charge would also apply). Nevertheless measuring the rejection behaviour of inorganic solutes provides a useful qualitative characterisation tool for NF membranes, providing information on relative pore size and charge properties.

For natural organic species the situation is less clear, although small neutral organics would tend to have rejections based on size exclusion. However, Bowen et al. [7] showed that while the effective pore size of NF membranes determined by uncharged organic solutes was valid for ions, the opposite was not true. Nghiem et al. [19] have used organics to characterise membranes and model retention for well defined LMM organics, but for complex mixtures as those of NOM behaviour is less predictable. Hence the rejection of poorly defined and complex organics such as humic substances remains more experimental. Not surprisingly, a significant variation in NOM rejection by NF has been observed for different surface waters [20]. However some of the trends observed include,

hydrophobic fractions of NOM appear to be best retained [21, 22],

acid pH favours lower and neutral pH relatively high NOM rejections [22],

ionic species may promote conformational changes in NOM fractions that can increase rejection $[22,23]$.

Inevitably fouling further complicates the NF rejection behaviour of waters containing NOM. The role of calcium in this phenomena has been observed by several researchers [24, 25]. The calcium can sequester the HA and FA species, coagulate the organics [26] and also provide a bridge binding the negatively charged molecules to negatively charged membranes [27]. This type of fouling can have two competing effects on NF rejection,

(i) it can increase retention of both calcium and HA fractions involved, and

(ii) if a distinct fouling layer develops it can provide an 'unstirred' boundary layer which will leak more of those species which have partial rejection.

In this paper we examine NF of waters containing NOM, NOM fractions, standard humic and fulvic acids and cations. Four membranes ranging from tight NF to tight UF are used and have been well characterised in terms of surface charge and retention of single species. The aim is to link the performance (rejection of bulk organics, LMM acids and flux decline) for a range of feed solutions with the membrane characteristics and to identify the type of membrane most suited to NOM removal from natural waters. In addition the permeating organic fractions are characterised in order to understand the mechanism of rejection for the smaller organics that could be a range of trace contaminants such as persistent organic pollutants or assimilable organic carbon (AOC). 


\section{MATERIALS AND METHODS}

\subsection{Membranes}

Nanofiltration membranes were obtained from Fluid Systems in San Diego, USA (now Koch Membrane Systems). Thin film composite (TFC) membranes were chosen due to their low fouling characteristics compared to the competing polysulphone membranes. Three TFC membranes were selected: TFC-ULP, TFC-S and TFC-SR. A cellulose acetate membrane (CA-UF) was also selected due to its high organics retention.

The CA-UF membrane is classed as a UF membrane but exhibits some salt rejection. The cut-off was specified to be about $5 \mathrm{kDa}$ and the material is non-ionogenic cellulose acetate.

The TFC membranes are chemically modified (different additives and post-treatments in the manufacturing process) to render the membranes more hydrophilic, but more details were not available. The manufacturer estimates the thickness of the active laver of the TFC membranes to be 150 to $200 \mathrm{~nm}$. For the TFC-SR membrane a different monomer was used compared to the other TFC membran While the TFC-S and TFC-ULP membranes are me from (1) acid chloride (a bezene ing whe the fabricated from a mixture of cyclo-aliphatic amine with acid chloride. This means that the TFC-S and TFC-ULP membranes have both positive and negative functional groups, whereas the TFC-SR membrane has negative functional groups only. Marker tests with $1 \%$ glucose $(180 \mathrm{Da})$ solutions at $\mathrm{pH}$ 6-7 showed a rejection of $94.4 \%$ and $90.6 \%$ for the TFC-SR and TFC-S membranes, respectively. Rejection of the TFC-ULP membrane is expected to be higher [28].

\subsection{Chemicals, Organics and Background Electrolyte}

The chemicals used were of analytical grade and supplied by Ajax Chemicals, Australia. Humic Substances were purchased from the International Humic Substances Society (IHSS, USA). Suwannee River Stream Reference Humic and Fulvic Acid were used. MilliQ water with a quality of $>18 \mathrm{M} \Omega / \mathrm{cm}$ was used for all experiments and preconditioning of membranes. NOM was concentrated using reverse osmosis and freeze dried. The raw water was obtained from the Mooney Dam (NSW, Australia) and pretreated with microfiltration prior to concentration and the product NOM well Australia) and pretreated with microfiltration prior to concentration and the product NOM w
characterised [29]. The NOM contains natural salts and their concentrations are shown in Table 1. characterised [29]. The $\mathrm{NOM}$ contains natural salts and their concentrations are shown in Table 1. $1 \mathrm{M} \mathrm{NaOH}, 1 \mathrm{M} \mathrm{HCl}$ and $1 \mathrm{M} \mathrm{NaCl}$ were used for $\mathrm{pH}$ and ionic strength adjustment. All glassware used
was soaked in $5 \mathrm{M} \mathrm{KOH}$ for $24 \mathrm{~h}$ and then rinsed with water to remove any organic contamination. Glassware used for inorganics was cleaned with $1 \mathrm{M}$ sulphuric acid

The background solution consisted (if not indicated otherwise) of $0.5 \mathrm{mM} \mathrm{CaCl}, 1 \mathrm{mM} \mathrm{NaHCO}_{3}$ and $20 \mathrm{mM} \mathrm{NaCl}$. The relatively high background electrolyte was required to compensate for variations in solution chemistry. For high calcium concentrations, the total ionic strength was adjusted as conductivity $(2 \mathrm{mS} / \mathrm{cm})$

\subsection{Equipment and Filtration Protocol}

All experiments were carried out in a magnetically stirred batch cell (volume of $185 \mathrm{~mL}$, membrane area $\left.21.2^{*} 10^{-4} \mathrm{~m}^{2}\right)$ at a controlled pressure of $500 \mathrm{kPa}$, pressurised with instrument air. All stirred experiments were stirred at $400 \mathrm{rpm}$ (measured with a Philips PR 9115/00 stroboscope). A reservoir of $1.5 \mathrm{~L}$ volume was connected to the stirred cell for pure water flux measurements. A Mettler Toledo PR 2002 balance connected to a PC was used to measure/calculate permeate weight/flux. Temperature was controlled at $20 \pm 1{ }^{\circ} \mathrm{C}$ using a waterbath.

$185 \mathrm{~mL}$ of feed solution was placed in the stirred cell after filtration of MilliQ water for $1 \mathrm{~h}$ at 10 bar (for membrane compaction) and $30 \mathrm{~min}$ at $5 \mathrm{bar}$ (for pure water flux determination). $120 \mathrm{~mL}$ of the the cell for fully retained species. 1 permeate samples were taken of $40 \mathrm{~mL}$ each.

The mass transfer coefficient was determined to be $1.81 \cdot 10^{-6} \mathrm{~ms}^{-1}$ at $400 \mathrm{rpm}$ and did not vary with membrane type; without stirring the mass transfer coefficient decreased to approximately $0.14 \cdot 10^{-6}$ $\mathrm{ms}^{-1}[29]$.

\subsection{Analytical Methods}

UV/VIS Spectrophotometry

A Varian Cary 1E Spectrophotometer was used to determine the rejection of UV absorbance as a sum parameter of rejection. A wavelength scan from 190 to $500 \mathrm{~nm}$ was performed for each sample, while the value at $254 \mathrm{~nm}$ was used to calculate rejection. Samples were measured against a MilliQ reference without $\mathrm{pH}$ adjustment, following the suggested standard method for surface water analysis [30]. The without $\mathrm{pH}$ adjustment, following the suggested standard method for surface water analysis [30]. The
$\mathrm{UV}$ scans for the four types of organics used have been published elsewhere [29]. UV absorbance is UV scans for the four types of organics
attributed to the aromatic structures [31].

\section{Total Organic Carbon (TOC)}

Total organic carbon was measured with a Skalar 12 TOC Analyser. The method is based on UVPersulfate oxidation with a FID detector. D-Glucose was used as the standard. Oxidation efficiencies for the organics used were determined separately, which enabled the calculation of absolute concentrations. TOC analysis was used to determine FA, HA, NOM as well as dextran concentrations.

\section{Ion Chromatography (IC)}

Ion chromatography (IC) was used for chloride determination for NF rejection experiments in the absence of organics. Anions could not be analysed using IC in the presence of organics, as humic substances interfere with the analysis [32]. A Millipore Waters Model 590 instrument was used with a Model 430 Conductivity detector. The eluent used was $0.68 \mathrm{gL}^{-1}$ boric acid $\left(\mathrm{H}_{3} \mathrm{BO}_{3}\right), 0.235 \mathrm{gL}^{-1}$ gluconic acid anhydride $\left(\mathrm{C}_{6} \mathrm{H}_{10} \mathrm{O}_{6}\right)$ and $0.3 \mathrm{gL}^{-1}$ lithium hydroxide $\left(\mathrm{LiOH} \cdot 6 \mathrm{H}_{2} \mathrm{O}\right)$.

\section{Inductively Coupled Plasma Atomic Emission Spectroscopy (ICP-AES)}

A Perkin Elmer Optima 3000 ICP-AES Instrument was used to determine the cation content of solutions. Samples were diluted with nitric acid. All vials used were cleaned with $1 \mathrm{M}$ sulphuric acid.

\section{Membrane Zeta Potential}

Streaming potential in background solution $\left(10 \mathrm{mM} \mathrm{NaCl}, 1 \mathrm{mM} \mathrm{NaHCO}\right.$ and $\left.0.5 \mathrm{mM} \mathrm{CaCl}_{2}\right)$ was measured using a Brookhaven Instruments Corp. BI-EKA commercial instrument. Childress and Elimelech described the measuring cell and zeta potential calculation in detail [13]. The membrane zeta potential is calculated from the thin channel streaming potential using the Helmholtz-Smoluchowski equation.

A different apparatus was used for the streaming potential measurements with individual electrolytes (see [14]). The induced potential difference, i.e., the streaming potential, was measured using a pair of (sec 14 . The in A separated by porous PTFE diaphagms (Ag/AgCl refence system, porous PTFE diaphragm, nonflow, double junction filled with gelled electrolyte). The dimensions of the channel between the two pieces of a sample were: height $0.4 \mathrm{~mm}$, width $19 \mathrm{~mm}$ and length $60 \mathrm{~mm}$.

The membranes were cleaned from preservatives and kept under pressure $(2 \mathrm{bar}$ for $1 \mathrm{~h})$ before starting the measurements. Between runs the membranes were stored in water.

\section{Contact Angle Measurements}

Contact angles were determined using the conventional sessile drop technique with $\mathrm{MilliQ}$ water as the reference liquid. This technique was also used by Jucker and Clark [33] who found that hydrophobic UF me lan also used contact angle measurements for membrane and fouling characterisation $[34,35]$. 


\section{Liquid Chromatography - Organic Carbon Detection (LC-OCD)}

This method consists of three size exclusion chromatography columns which divide the organic carbon into several fractions as a function of size, but also hydrophobic and ionogenic characteristics [36]. A sample of up to $3 \mathrm{~mL}$ is injected into the instrument and filtered in-line with a $0.45 \mu \mathrm{m}$ filter. The deposit on the filter is backwashed after 5 minutes and directly analysed with the TOC analyser to determine the particulate organic carbon content $(\mathrm{POC})$.

The organic carbon detector used is based on a thin film reactor principle ("Gräntzel" type). The inorganic carbon is removed by a stripping process in the top of the reactor. The organic carbon is oxidised to $\mathrm{CO}_{2}$ using a radiological method of splitting water molecules radiated with light at $185 \mathrm{~nm}$. The $\mathrm{CO}_{2}$ was analysed using non-dispersive IR. The detection limits are in the low $\mu \mathrm{gL} \mathrm{L}^{-1}$ concentrations. UV absorbance was also analysed in parallel. Samples were diluted prior to injection. HS-hydrolysates are probably formed in waters by very slow UV oxidation. It is assumed that these compounds are highly substituted aromatic and conjugated acids, or they also may be intermediates in the formation of HS. Low molecular mass acids are C1 to C5 anions. The low molecular mass neutrals and amphiphilics are compounds like alcohols, aldehydes, ketones, and amino acids. Polysaccharides (UV inactive) are the EPS of algae and bacteria. They are a sign of biological activity.

The interest for this work is the size or molecular mass of the organic substances used and the characterisation of the organics remaining in NF permeates. The chemical characteristics of the compounds are discussed elsewhere [29].

\section{RESULTS AND DISCUSSION}

4.1 Membrane Characterisation

\section{Pure Water Flux and Hydrophilicity}

Membrane pure water fluxes, dextran rejection, estimated pore diameter and contact angles for the membranes used are shown in Table 2. Except for the TFC-ULP membrane, which appears to be a less porous membrane with about half the pure water flux of the other membranes, the pure water fluxes of the membranes (TFC-S, TFC-SR and CA-UF) are very similar.

The contact angles were measured immediately after deposition, to avoid errors due to spreading of the drop caused by surface capillary forces. The results reported in Table 2 indicate that the TFC-SR membrane is a very hydrophilic membrane, whereas the TFC-S, TFC-ULP and the CA-UF membranes are only moderately hydrophilic.

\section{Membrane pore size}

The aim of the pore size estimation was not to produce an absolute value for pore size or molecula mass cut off, but to determine which of the four membranes is more open. The pore size was estimatetd based on the equivalent sphere diameter of the rejected molecules using the Stokes Einstein equation and the relationship given by Worch [37]. The method is described in detail by Schäfer [29] Dextran 1000 (molecular mass 1000 g.mol-1). standard was chosen and rejection experiments were carried out at a dextran concentration of about $50 \mathrm{mgL}^{-1}$ at $\mathrm{pH} 8$ in the absence of other salts. The feed organic carbon concentration (TOC) was $19.4 \mathrm{mgL}^{-1}$. Dextran was chosen as it is not expected to interact strongly with membrane material [38].

The results in Table 2 show that in terms of dextran rejection, the TFC-SR membrane is the 'tightest' membrane, followed by the TFC-S. The TFC-ULP membrane is also reasonably tight, whereas the CAUF membrane is clearly a UF membrane with a very low dextran rejection. The radius of a dextran UF mentran membranes and dextran have a distribution of pore size/cut-off and molecular mass, respectively.

membranes and dextran have a distribution of pore size/cut-off and molecular mass, respectively.
The manufacturer provided marker test data for some of these membranes; the CA-UF membrane The manufacturer provided marker test data for some of these membranes; the CA-UF membrane
showed about $90 \%$ and $76 \%$ rejection with $100 \mathrm{mgL}^{-1}$ dextran with molecular masses of 40 and 10 $\mathrm{kD}$, respectively. TFC-S and TFC-SR membranes were challenged with a $1 \%$ glucose (180 Da) solution and rejections of $94.8 \%$ and $90.6 \%$ were obtained, respectively, while those of lactose ( $342 \mathrm{Da}$ ) were $>99 \%$ for both membranes.

Table 3 shows charge and size of the organics used in this study. Except for the hydrophilic fraction of NOM (see [29] for details on how these fractions were obtained) all organics used have a larger average molecular mass than dextran 1000 and the rejection of these bulk organics would thus be expected to be higher.

\section{Membrane Zeta Potential}

When zeta potentials were measured using the electrolyte commonly used for zeta potential analysis $(1 \mathrm{mM} \mathrm{KCl}$ ) all membranes showed similar trends with isoelectric points of about 4.0 (except for TFC$\mathrm{SR}$ at $\mathrm{pH}$ 5.5) and negative charge values asymptoting to -5 to $-10 \mathrm{mV}$ at high $\mathrm{pH}$ (Figure $1 \mathrm{~A}, \mathrm{~B}, \mathrm{C}$ and D). Zeta potential varies with solution chemistry and it is of interest in this study to determine the surface charge with the solution chemistry used in the experiments. The data for $1 \mathrm{mM} \mathrm{NaHCO} 3$ were very similar to $\mathrm{KCl}$. In $10 \mathrm{mM} \mathrm{NaCl}$ all the membranes showed more negative zeta potentials; the TFCs showed quite large effects. These results can be explained by adsorption of chloride ions from solution $[33,39,40]$. Ion adsorption depends on concentration and this explains the observed charge dependence well $[15,41]$. In $0.5 \mathrm{mM} \mathrm{CaCl} 2$ all membranes shifted to a slightly more positive trend (asymptotic to a less negative zeta potential), presumably due to calcium binding to the membranes. In general the CA-UF membrane was less sensitive to the ionic composition although zeta potentials were slightly more negative in the $10 \mathrm{mM} \mathrm{NaCl}$ and slightly more positive in the $0.5 \mathrm{mM} \mathrm{CaCl}_{2}$.

When the zeta potentials were tested in the typical background solution used for tests $(0.5 \mathrm{mM} \mathrm{CaCl}$, $1 \mathrm{mM} \mathrm{NaHCO}, 20 \mathrm{mM} \mathrm{NaCl}$ ), the differences between the membranes were significant as shown in Figure 2. The differences tend to reflect the responses to chloride, i.e. TFC-SR and TFC-ULP show most negative zeta potentials in the background solution and the most effect in $10 \mathrm{mM} \mathrm{NaCl}$ (Figure $1 \mathrm{~A}$ and C). The TFC-S showed less response in the background solution which may be due to a greater response to calcium cations (Figure 1B)

The zeta potential characterisation provides a qualitative insight into the charge properties and the differences between the membranes used. However, zeta potential only gives the average charge of a surface. In reality, membranes have a heterogeneous surface and charge depends on the local concentrations of functional groups. Also, the surface roughness may have an impact on the measured concentation (10] have of sinally, fouling may also alter zeta potential. For example, Elimelech $e t$ al. [40] have shown that the adsorption
of humic acid on CA and TFC membranes leads to a significant increase in negative surface charge.

\subsection{Solution Characterisatio}

The nanofiltration of solutions of different $\mathrm{pH}$ is sensitive to the speciation of ions in solution as indicated by Simpson et al. [18]. This is of particular concern for the carbonate system [42] Characteristics such as charge, ionic molar mobility, diffusivity, mobility and hydrated radius which may affect the rejection of ions in NF are shown in Table 4.

\subsection{Salt Rejection in the Absence of Organics}

The salt rejections and flux ratios at the end of filtration at $\mathrm{pH} 4.5,8$, and 10 are shown in Table 5 . Those results present a baseline of salt rejection before organics are added to the solutions in subsequent experiments. The three values represent the rejection after the collection of 40,80 , and 120 $\mathrm{mL}$ of permeate, respectively. Jwo is the pure water flux before the experiment. The water flux did not change measurably with $\mathrm{pH}$, which is in accordance with the results of Hagmeyer [39]. This suggests that there were no changes in effective pore size or electroviscous effects.

The TFC-ULP membrane showed high rejection of $\mathrm{Ca}, \mathrm{Na}$ and chloride, with a slightly increasing trend with $\mathrm{pH}$. This membrane has a strong negative charge with variation over the $\mathrm{pH}$ range (see Figure 2) but the rejections imply separations dominated by size exclusion with subtle variations due to 
charge interactions. The fact that this membrane rejected only $88 \%$ dextran 1000 suggests that its ion rejection incorporates some charge mechanism.

The TFC-S membrane showed greater selectivity between $\mathrm{Ca}$ (high rejection) and $\mathrm{Na}$ (moderate rejection). Rejection trends with $\mathrm{pH}$ were small possibly reflecting the relatively shallow zeta potential profile (Figure 2) for this membrane. Overall, the results suggest that the retention mechanism is predominated by size exclusion. Rejection for the TFC-SR membrane showed unusual, but reproducible trends with a significantly
lower rejection for sodium as well as a strong pH effect. Rejection is lowest at $\mathrm{pH} 8$ which can neither be explained by "pore size", nor charge. The TFC-SR membrane has the highest charge, highest hydrophilicity, and smallest pore size. However, there is no difference in membrane charge between hydrophilicity, and smallest pore size. However, there is no difference in membrane charge between
$\mathrm{pH} 8$ and 10 . The effect observed can possibly be explained by solution speciation phenomena. $\mathrm{pH} 8$ and 10 . The effect observed can possibly be explained by solution speciation phenomena.
Carbonate and chloride are the co-ions in solution. At pH 8, carbonate is present in its monovalent Carbonate and chloride are the co-ions in solution. At $\mathrm{pH}$ 8, carbonate is present in its monovalent balance, cations (or counter-ions) are also rejected less. The flux of this membrane showed less decline due to a lower sodium and chloride rejection which results in a lower osmotic pressure of the concentrate.

As expected of a UF membrane, the CA-UF membrane shows a salt rejection close to zero. The values of $15 \%$ observed are probably due to initial ion adsorption in the membranes or due to experimental error, which is relatively high at such low rejections.

Overall, the flux ratios $(\mathrm{J} / \mathrm{J} \mathrm{w} 0$, solution flux after filtration of $120 \mathrm{~mL}$ of solution relative to the pure water flux before the experiment) correspond well to the salt rejections. A low value of $\mathrm{J} / \mathrm{J}_{\mathrm{w}}$ indicates concentration polarisation and osmotic pressure effects due to the accumulation of ions at the membrane surface and an increase in cell concentration. In these tests flux decline was fully reversible. The flux of the CA-UF membrane consistently increased after salt filtration, probably due to an increased wettability or hydrophilicity after ion adsorption in the membrane.

In summary, based on salt retention itself, a membrane with the properties of the TFC-SR shows very interesting characteristics for water treatment applications, whereas the TFC-ULP and TFC-S membranes may remove more sodium than required. The increased sodium rejection leads inevitably to a higher concentration on the concentrate side of the membrane and the resulting osmotic pressure reduces permeate flux and increases energy demand. It is therefore important to select a membrane reduces permeate flux and increases energy dem
which does not remove more salt than necessary.

\subsection{Organics and Salt Rejection in Synthetic Surface Water Solution}

IHSS fulvic acid (FA) was used for rejection experiments as FA is smaller (in molar mass) than IHSS humic acid (HA). Therefore, the rejection due to the size of this compound should be the lowest While the NOM is still smaller than FA, the impurities in the NOM (and its HA and FA fractions) and the fact that its contents are largely uncharacterised make the use of IHSS FA more suitable for fundamental studies.

\section{Effect of Salt Type}

Experiments were carried out with the TFC-SR membrane to examine the effect of salt composition on rejection of organics and cations and flux in the presence of FA. This membrane was selected due to the high organics rejection and low salt rejection which is of advantage in water treatment.

The data are summarised in Table 6. As a general trend, in most experiments the rejection of the wellretained species increases from sample 1 to 3 . This may be the case for a number of reasons. Firstly, the concentration in the cell increases during filtration (rejection results were corrected for this variation in cell concentration). Secondly, the composition of the feed changes as a function of rejection, with the less rejected compounds being depleted in the cell. Thirdly, the variation of the membrane charge due to fouling and adsorption effects may alter the rejection behaviour of the membranes. Organics rejection is consistently high.

The results in Table 6 show significant effects of calcium concentration on the rejection and/o transmission of other species (organics and sodium), which is believed to be due to complexation and fouling which has been shown to be exacerbated by calcium (Schäfer et al. [24], Hong and Elimelech [25]) in the case of FA and due to charge neutralisation (Donnan effect) in the case of sodium. Figure 3 shows DOC transmission versus calcium concentration; at each concentration the transmissions of the three sequential samples are shown in the form of a variation bar around the average value. At all conditions the transmission dropped over time (sample1>sample2>sample3). Transmission also conditions the tran showed a maximum at abou $0.5 \mathrm{mM}$ Ca which is typical of perfor mechanisms. The increasing trend in transmission can be attributed to the effect of Ca-FA accumulation and fouling causing an unstirred boundary layer which raises the wall concentration of (partially) rejected species. The decreasing trend with Ca concentration could be due to Ca-FA complexation which sequesters the FA or aggregation [26] or due to changes in the fouling morphology at high Ca concentrations (Schäfer et al. [24]).

Cation rejection depends strongly on electrolyte composition. The Ca rejection increased with $\mathrm{Ca}$ concentration which may be partially explained by $\mathrm{Ca}-\mathrm{FA}$ complexation, but could also be related to the increased Na passage. Figure 4 presents sodium rejection as a function of calcium concentration and shows a significat drop in rejection, even to negative values. This is classic nanofiltration (pume' the miltration monovalent ions across the membrane [39]. The behaviour has been explained by the Donnan effect which predicts greater pumping (more negative rejection) as the ratio of permeating /non permeating species (i.e. $\mathrm{Na} / \mathrm{Ca}$ ) decreases. This explains the lower $\mathrm{Na}$ rejections for sample 3 in Figure 4. At the highest $\mathrm{Ca}$ concentration the negative rejection effect is less evident. This may be another manifestation of the unstirred boundary layer caused by fouling deposition. However, in this situation the unstirred boundary layer would become depleted in the 'pumped' ion lowering the permeate concentration and raising the rejection. Also shown on Figure 4 is the Na rejection at $2.5 \mathrm{mM} \mathrm{Ca}$ and $20 \mathrm{mM} \mathrm{NaCl}$. The rejection was positive (34 to $40 \%$ ) and this is because the $\mathrm{Na} / \mathrm{Ca}$ ratio was high and therefore not favourable to ion 'pumping'. In summary, Figure 3 and Figure 4 show the importance of ionic composition on rejection and transmission of organic and inorganic species with certain NF membranes. The role of calcium induced fouling is apparent in the trends observed.

\section{Effect of Membrane Type}

Rejection results at $\mathrm{pH} 8$ for $\mathrm{FA}$ are summarised in Table 7 for the four membranes used in this study The TFC-ULP and TFC-S membranes have very high ion rejections of $>80 \%$ for sodium and $>90 \%$ for calcium. Values are comparable to those obtained in the absence of organics (Table 5).

UV $254 \mathrm{~nm}$ is rejected at a higher level than DOC, with a difference of about $10 \%$. This indicates a fractionation of organic matter into more or less absorbing functional groups by the membrane (see below for further details). The organics with a smaller molar mass absorb less UV (with the exception of the relatively large polysaccharides), and it is these small compounds which pass through membranes more easily [36]. The TFC-SR membrane rejects a higher percentage of DOC and UV $254 \mathrm{~nm}$ than the other two
membranes. In contrast, cations are rejected far less, sodium to about $40 \%$ and calcium to about $70 \%$ . The about $70 \%$ The resence between DOC and UV is reduced, as both are rejected almost entrely. The reason for this higher organics retention and lower salts retention is not clear. In terms of membrane properties the TFC-SR is more highly charged (see Figure 2) and more hydrophilic (Table 2); it also showed the highest rejection of dextran. The behaviour may be due to a subtle interplay between effective pore size, charge and surface chemistry.

The CA-UF membrane has the lowest rejection of organics, and the ion rejection is slightly increased compared to the absence of organics. This may indicate interactions between the retained organics ${ }_{10}$ 
and the cations. This membrane shows very interesting flux behaviour, with no decline at all over the experiments and a higher pure water flux after the experiments. This indicates the lack of concentration polarisation or osmotic pressure effect at the low salt rejection and the likely adsorption of ions which render the membrane more hydrophilic. The smooth membrane surface would also influence this. For situations requiring moderate organics removal (say up to $70 \%$ ) with low salt retention this type of tight UF membrane would be attractive.

\section{Effect of Organic Type and $\mathrm{pH}$}

The effect of organic type (FA, HA or NOM and their fractions) on rejection was examined. The results for the TFC-SR membrane are presented in Table 8 . A general observation is that organics rejection (as DOC) tended to increase during the experiments. The transmission data for FA (DOC) in Figure 3 show the same trend and was explained as fractionation with gradual loss of the smaller species. Organics rejection as UV was very high throughout the experiments and is a measure of near complete retention of the larger aromatic fractions (see also below).

According to the DOC measurements, IHSS FA is retained more effectively than either HA or NOM. At first sight it is somewhat surprising that FA is retained best as IHSS HA has a larger molar mass than FA (Table 3). However, there are several factors to consider. The molecular mass (or size) determined by size exclusion chromatography is an average value and does not allow for the greater polydisperity of the HA. It would be the lower mo me polych in the FA (Table 3) would tend to give it greater charge interaction with the membrane. Complexation or interaction with calcium, as evidenced in Figure 3, would also play a role in the relative permeability of the organic species. The UV absorbing species of the three organics examined were retained almost completely under all conditions (Table 8).

For the cations the $\mathrm{Na}$ rejection was typically lowest at $\mathrm{pH} 8$, similar to the trend in Table 5 without organics present (TFC-SR). The reason for this trend is not clear, but could be due to competing effects of speciation, membrane charge and Donnan 'pumping' discussed earlier with Figure 4. Calcium rejection was typically highest at low $\mathrm{pH}$, when the membranes are less negatively charged and the $\mathrm{Ca}$ is fully dissociated.

The effect of organics on the rejection of the cations did not show clear trends. Comparing the TFCSR data in Table 5 (no organics) with the data in Table 8 indicates that,

- at $\mathrm{pH} 4.5$ the Ca rejection decreased and the Na rejection increased, particularly with IHSS HA and NOM;

at $\mathrm{pH} 8$ the $\mathrm{Ca}$ and $\mathrm{Na}$ rejections increased or were unchanged;

at $\mathrm{pH} 10$ the $\mathrm{Ca}$ and $\mathrm{Na}$ rejections decreased or were unchanged.

The increased rejections at $\mathrm{pH} 8$ could be due to increased membrane charge due to organic adsorption or sequestering due to complex formation. The decreased rejections at $\mathrm{pH} 10$ could have been caused by fouling and by the unstirred boundary layer phenomena. Confirmation of the trends at $\mathrm{pH} 8$ are given in Table 9 where the HA concentration was increased from 2.5 to $7.5 \mathrm{mg} / \mathrm{L}$; both Ca and Na rejections increased as $\mathrm{HA}$ concentration increased. Interestingly, the flux ratio also increased with $\mathrm{HA}$ con cont hypothesis is sto complexity of the organic matter itself and the resulting complexity of interactions precise conclusions cannot be drawn. What is most apparent is the significant difference between UV and DOC rejection which invites further investigation of this phenomenon.

\section{Permeate analysis by LC-OCD}

Liquid chromatography organic carbon detection (LC-OCD) was used to investigate possible fractionation of organics by NF membranes. This allows the understanding of the rejection mechanism of smaller molecules. Figure 5 demonstrates the selectivity of the TFC-S membrane towards certain fractions of the NOM. While the humics and hydrolysates were almost completely retained, the LMM acids fraction passes through the membrane. It appears that polysaccharides which are largely uncharged compounds also permeate through the membranes. It should be noted that the feed sample was diluted 1:25 for the analysis.

Figure 6 shows permeate characteristics as a function of $\mathrm{pH}$ for the TFC-S membrane with an IHSS HA feed (also diluted 1:25). The humics and hydrolysates were again fully retained. The rejection of the LMM acids was low (and similar) at $\mathrm{pH} 4.5$ and 8 , but was substantially higher at $\mathrm{pH} 10$. These acids dissociate with increasing $\mathrm{pH}$ and this increased rejection can be attributed to charge interaction (repulsion). The nature and origin of the neutrals and amphiphilics peak is unclear. While the fraction in the permeate was also found in the feed, the rejection is much lower than that of the LMM acids.

The results confirm that charge interactions are important for a component of the organics with regards to rejection. While the humics and hydrolysates are retained by size exclusion due to their relatively large size, the smaller compounds demonstrate $\mathrm{pH}$ (and thus charge) dependence. Rejection experiments in this section failed to show this effect with DOC and UV analysis due to the high proportion of organics larger than the pore size in the samples. The increased rejection of the LMM compounds at high $\mathrm{pH}$ indicates that the membrane pores are effectively perceived as smaller due to the repulsive charge layers. It should be noted here that smaller compounds may still pass through such pores if the charged layers of the pore do not overlap with the charged layers or the molecules.

\subsection{Effect of Stirring on Rejection}

as a final investigation the influence of stirring (in the stirred cell) on rejection will be investigated. Stirring influences concentration polarisation and, therefore, mass transfer across the membrane. The wall concentration of solute increases at lower stirring and therefore the rejection is expected to decrease due to increased diffusion across the membrane.

The CA-UF membrane has the largest pores and with the solute having a very similar size to the pores, DOC rejection dropped from values like $72 \%$ for stirred conditions to $-80 \%$ unstirred (results not shown). This implies very high leakage under unstirred conditions. Similar trends (i.e. much lower rejections) were seen for UV, calcium and sodium rejection. These results are of interest considering the tendency to operate water treatment UF membranes under 'dead-end' (unstirred) hydrodynamic conditions to reduce energy costs.

For a tighter NF membrane (TFC-S, see Figure 7), rejection decreases by about $50 \%$ without stirring at $\mathrm{pH} 8$. The stirred experiment was repeated to demonstrate reproducibility. While a similar effect is $\mathrm{pH}$ 8. This clealy visibe for this me. Hent the solute to pore size ratio. Hence the rejection is by no means a simple size exclusion effect as often assumed for organic matter. Charge interactions as well
and require consideration when designing NF processes.

\section{CONCLUSIONS}

The paper focuses on the difference in rejection between bulk organic matter and LMM acids by four $\mathrm{NF}$ membranes following a substantial characterisation of the rejection behaviour of those membranes in the absence of organics.

While the retention of inorganic species is generally well understood, in the presence of organic matter solute-solute and solute-membrane interactions become more complex. This paper investigated some (n) some of those complexities and contributes to understanding by differentiating between the (mostly) size exclusion effects observed for bulk organic matter, which is supported by an independence of retention from solution chemistry that may affect size and shape of the molecules as well as membrane charge. For LMM acids, smaller molecules with a negative charge, the retention was strongly dependent on charge with retention increasing as the charge repulsion between molecules and membranes increased. This indicates that the molecules are large enough (or of a similar order of size as the pores) to experience repulsive effects as opposed to a scenario where molecules are substantially smaller than pores and repulsive forces do not influence rejection. 


\section{ACKNOWLEDGEMENTS}

Georg Hagmeyer from IWW, University of Duisburg, Germany is thanked for membrane zeta potential measurements with the Brookhaven Instrument. Dr. Stefan Huber (DOC Labor, Germany) is acknowledged for LC-OCD analysis of the organics.

The German Academic Exchange Service (DAAD) and the CRC for Water Quality and Treatment are thanked for providing a scholarship and project funding to A.I. Schäfer. We also acknowledge Koch samples and marker test results.

\section{REFERENCES}

[1] J. S. Taylor, E. P. Jacobs, Reverse Osmosis and Nanofiltration, in Water Treatment Membrane Processes (eds. J. Mallevialle, P. E. Odendaal, M. R. Wiesner) McGrawHill, New York, 1996, 9.1-9.70.

[2] J. Mallevialle, P. E. Odendaal, M. R. Wiesner, Water Treatment Membrane Processes McGraw-Hill1996.

[3] J. G. Jacangelo, J. DeMarco, D. M. Owen, S. J. Randtke, Selected Processes for Removing NOM: An Overview, Journal AWWA Jan 95 (1995), 64-77.

[4] M. Siddiqui, G. Amy, J. Ryan, W. Odem, Membranes for the control of natural organic matter from surface waters, Water Research 34 (13) (2000), 3355-3370.

[5] M. Itoh, S. Kunikane, Y. Magara, Evaluation of nanofiltration for disinfection by-products control in drinking water treatment, Water Science and Technology: Water Supply 1 (5-6) (2001), 233-243.

[6] I. C. Escobar, A. A. Randall, Assimilable organic carbon (AOC) and biodegradable dissolved organic carbon (BDOC): complementary measurements, Water Research 35 (18) (2001), 4444-4454.

[7] W. R. Bowen, A. W. Mohammad, N. Hilal, Characterisation of nanofiltration membranes for predictive purposes - use of salts, uncharged solutes and atomic force microscopy, Journal of Membrane Science 126 (1997), 91-105.

[8] L. D. Nghiem, A. I. Schäfer, Trace Contaminant Removal with Nanofiltration, in Nanofiltration - Principles and Applications (eds. A. I. Schäfer, A. G. Fane, T. D. Waite) Elsevier, Oxford, 2004,

[9] W. Peng, I. C. Escobar, Rejection Efficiency of Water Quality Parameters by Reverse Osmosis and Nanofiltration Membranes., Environmental Science \& Technology 37 (2003), 4435-4441.

[10] E. M. Thurman, Organic Geochemistry of Natural Waters Martinus Nijhoff/Dr W. Junk Publishers: Dordrecht, 1985

[11] M. Nyström, L. Kaipia, S. Luque, Fouling and retention of nanofiltration membranes, Journal of Membrane Science 98 (1995), 249-262.

[12] K. Ghosh, M. Schnitzer, Macromolecular structures of humic substances, Soil Science 129 (5) (1980), 266-276.

[13] A. E. Childress, M. Elimelech, Effect of solution chemistry on the surface charge of polymeric reverse osmosis and nanofiltration membranes, Journal of Membrane Science 119 (1996), 253-268.

[14] A. Pihlajamäki, Electrochemical characterisation of filter media properties and their exploitation in enhanced filtration, PhD Thesis, Lappeenranta University of Technology, Lappeenranta, Finland, 1998.

[15] J. M. M. Peeters, Characterization of nanofiltration membranes, PhD Tesis, University of Enschede, Enschede, Netherlands, 1997.

[16] J. M. M. Peeters, M. H. V. Mulder, K. Keizer, H. Strathmann, in Euromembrane '95; 107112 Bath, United Kingdom, 1995.
[17] J. M. M. Peeters, M. H. V. Mulder, K. Keizer, H. Strathmann, H. Verweij, in Proc. of Colloid Science in Membrane Engineering; O 24 Toulouse, France, 1996.

[18] A. E. Simpson, C. A. Kerr, C. A. Buckley, The effect of $\mathrm{pH}$ on the nanofiltration of the carbonate system in solution, Desalination 64 (1987), 305-319.

[19] D. L. Nghiem, A. I. Schäfer, M. Elimelech, Removal of natural hormones by nanofiltration membranes: measurement, modeling, and mechanisms, Environmental Science \& Technology 38 (2004), 1888-1896

[20] S. C. Allgeier, R. S. Summers, in AWWA Membrane Technology Conference; 39-66 AWWA, Reno, Nevada, 1995.

[21] J. A. Nilson, F. A. DiGiano, Influence of NOM composition on nanofiltration, Journa AWWA May (1996), 53-66.

[22] W. Agui, S. Tamura, M. Abe, K. Ogino, Removal of dissolved humic substances from water with a reverse osmosis membrane, The Science of the Total Environment 117/118 (1992), $543-550$

[23] A. Braghetta, F. A. DiGiano, W. P. Ball, Nanofiltration of natural organic matter: $\mathrm{pH}$ and ionic strength effects, Journal of Environmental Engineering 123 (7) (1997), 628-641.

[24] A. I. Schäfer, A. G. Fane, T. D. Waite, Nanofiltration of natural organic matter: removal, fouling and the influence of multivalent ions, Desalination 118 (1998), 109-122.

[25] Hong, Elimelech, Journal of Membrane Science 132 (1997), 159-181.

[26] N. A. Wall, G. R. Choppin, Humic acids coagulation: influence of divalent cations, Applied Geochemistry 18 (2003), 1573-1582.

[27] S. Hong, M. Elimelech, Chemical and physical aspects of natural organic matter (NOM) fouling of nanofiltration membranes, Journal of Membrane Science 132 (1997), 159-181.

[28] D. Takigawa, personal communication, (July 1999),

[29] A. I. Schäfer, Natural Organic Matter Removal using Membranes: Principles, Performance and Cost CRC Press: Boca Raton, USA, 2001.

[30] A. Eaton, Measuring UV - absorbing organics: a standard method, Journal AWWA Feb 95 (1995), 86-90.

[31] G. V. Korshin, C.-W. Li, M. M. Benjamin, in Natural Organic Matter Workshop; 7 Poitiers, France, 1996

[32] E. Hoffmann, G. Marko-Varga, I. Csiky, J. Å. Jönsson, Multicolumn ion chromatographic determination of nitrate and sulfate in waters containing humic substances, Int. J. Environ. Anal. Chem. 25 (1986), 161.

[33] C. Jucker, M. M. Clark, Adsorption of aquatic humic substances on hydrophobic ultrafiltration membranes, Journal of Membrane Science 97 (1994), 37-52.

[34] C. R. Bouchard, J. Jolicoeur, P. Kouadio, M. Britten, Study of humic acid adsorption on nanofiltration membranes by contact angle measurements, The Canadian Journal of Chemical Engineering 75 (April) (1997), 339-345.

[35] C. Combe, E. Molis, P. Lucas, R. Riley, M. M. Clark, The effect of CA membrane properties on adsorptive fouling by humic acid, J. Membrane Sci. 154 (1) (1999), 73-87.

[36] S. A. Huber, Organics - The value of chromatographic characterisation of TOC in process water plants, Ultrapure Water (1998), 16-20.

[37] E. Worch, Eine neue Gleichung zur Berechnung von Diffusionskoeffizienten geloster Stoffe, Vom Wasser 81 (289-297) (1993),

[38] C. Combe, E. Molis, P. Lucas, R. Riley, M. M. Clark, The effect of CA membrane properties on adsorptive fouling by humic acid, Journal of Membrane Science 154 (1999), 73-87.

[39] G. Hagmeyer, Rückhaltung von binären und ternären Elektrolytmischungen durch Nanofiltrationsmembranen unter besonderer Berücksichtigung der Kohlensäurespezies, $\mathrm{PhD}$ Thesis, Gerhard-Mercator University Duisburg, Duisburg, Germany, 1999. 


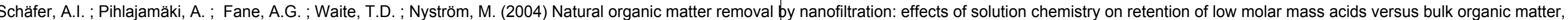
Journal of Membrane Science, 242, 1-2, 73-85. doi:10.1016/j.memsci.2004.05.018

[40] M. Elimelech, W. H. Chen, J. J. Waypa, Measuring the zeta (electrokinetic) potential of reverse osmosis membranes by a streaming potential analyzer, Desalination 95 (1994), 269286.

[41] W. R. Bowen, H. Mukhtar, Characterisation and prediction of separation performance of nanofiltration membranes, Journal of Membrane Science 112 (1996), 263-274.

[42] F. M. M. Morel, J. G. Hering, Principles and Applications of Aquatic Chemistry WileyInterscience: New York, 1993

[43] E. Worch, Eine neue Gleichung zur Berechnung von Diffusionskoeffizienten gelöster Stoffe, Vom Wasser 81 (1993), 289-297.

[44] T. Urase, J.-i. Oh, K. Yamamoto, Effect of $\mathrm{pH}$ on rejection of different species of arsenic by nanofiltration, Desalination 117 (1998), 11-18.

[45] E. L. Cussler, Diffusion mass transfer Cambridge University Press 1995

[46] P. Moulin, P. Manno, J. C. Rouch, C. Serra, M. J. Clifton, P. Aptel, Flux improvement by Dean vortices: ultrafiltration of colloidal suspensions and macromolecular solutions, Journal of Membrane Science 156 (1999), 109-130.

\section{TABLES}

Table 1 Salt content of the three organic samples used. The salt content is per $100 \mathrm{mg} \mathrm{L}^{-1} \mathrm{DOC}$ and is to be added to the background solution concentrations.

\begin{tabular}{llccc}
\hline & & IHSS HA & IHSS FA & NOM \\
\hline $\mathrm{Al}$ & {$\left[\mathrm{mgL}^{-1}\right]$} & 0.10 & 0.02 & 0.58 \\
$\mathrm{Ca}$ & {$\left[\mathrm{mgL}^{-1}\right]$} & 0.22 & 0 & 62.6 \\
$\mathrm{Fe}$ & {$\left[\mathrm{mgL}^{-1}\right]$} & 0.11 & 0 & 1.41 \\
$\mathrm{Na}$ & {$\left[\mathrm{mgL}^{-1}\right]$} & 1.52 & 0.23 & 296 \\
$\mathrm{~K}$ & {$\left[\mathrm{mgL}^{-1}\right]$} & 0.55 & 0.41 & 52.4 \\
\hline
\end{tabular}

Table 2 Measured permeability, average pure water fluxes, contact angle, dextran rejection and estimated pore diameter of clean membranes.

\begin{tabular}{lccccc}
\hline Membrane & $\begin{array}{c}\text { Average } \\
\text { Permeability } \\
{\left[\mathrm{Lm}^{-2} \mathrm{~h}^{-1} \text { bar- }{ }^{-1}\right]}\end{array}$ & $\begin{array}{c}\text { Average Pure } \\
\text { Water Flux } \\
\left.\text { at } 5 \text { bar [ [m-2 } \mathrm{h}^{-1}\right]\end{array}$ & $\begin{array}{c}\text { Contact Angle } \\
\text { of Clean } \\
\text { Membrane [0] }\end{array}$ & $\begin{array}{c}\text { Rejection of } \\
1000 \text { gmol-1 } \\
\text { Dextran [\%] }\end{array}$ & $\begin{array}{c}\text { Pore } \\
\text { Diameter } \\
{[\mathrm{nm}]}\end{array}$ \\
\hline TFC-ULP & 3.9 & $19.4 \pm 2.6$ & $40.9 \pm 2.1$ & 88.3 & $<0.6$ \\
TFC-SR & 9.2 & $45.8 \pm 6.1$ & $13.1 \pm 6.4$ & 97.2 & $<0.6$ \\
TFC-S & 9.9 & $49.4 \pm 5.9$ & $52.8 \pm 2.9$ & 94.6 & $<0.6$ \\
CA-UF & 10.0 & $49.9 \pm 4.2$ & $54.0 \pm 7.1$ & 17.3 & 3.7 \\
\hline
\end{tabular}

Table 3 Acidity, average molecular mass and molecule diameter of the organics used (1[33], $\left.{ }^{2}[29]\right)$.

\begin{tabular}{lcccc} 
Type of Organic & \multicolumn{2}{c}{$\begin{array}{c}\text { Acidity }\left[\mathrm{meqg}^{-1}\right] \\
\text { Carboxylic/Phenolic }\end{array}$} & $\begin{array}{c}\text { Molecular Mass } \\
{\left[\mathrm{g} \mathrm{mol}^{-1}\right]}\end{array}$ & $\begin{array}{c}\text { Molecule Size }^{*} \\
{[\mathrm{~nm}]}\end{array}$ \\
\hline IHSS HA & $3.4^{1}$ & $1.5^{1}$ & 2747 & 1.35 \\
IHSS FA & $4.0^{1}$ & $2.9^{1}$ & 1532 & 0.99 \\
Mooney NOM & $5.1^{2}$ & $1.3^{2}$ & 1381 & 0.94 \\
NOM HA Fraction & - & - & 1857 & 1.10 \\
NOM FA Fraction & - & - & 1318 & 0.92 \\
NOM Hydrophilic Fraction & - & - & 970 & 0.79 \\
\hline
\end{tabular}

* calculated from molecular mass after Worch [43]. 


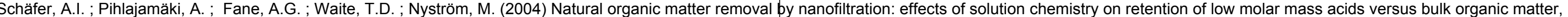
Journal of Membrane Science, 242, 1-2, 73-85. doi:10.1016/j.memsci.2004.05.018

Table 4 Characteristics of ions in solution. The molar mobilities of species like $\mathrm{NaCO}_{3}{ }^{2-}$ or $\mathrm{CaCO}_{3}$ - are not available, but values are expected to be lower than for $\mathrm{HCO}_{3}^{2-}([15,44-46])$.

\begin{tabular}{lcccc}
\hline Ion & $\begin{array}{c}\text { Ionic Molar Mobility } \\
{\left[\mathrm{mol} \mathrm{m}^{2} \mathrm{~J}^{-1} \mathrm{~s}^{-1}\right]}\end{array}$ & $\begin{array}{c}\text { Diffusivity } \\
{\left[\mathrm{m}^{2} \mathrm{~s}^{-1}\right]}\end{array}$ & $\begin{array}{c}\text { Mobility } \\
{\left[\mathrm{m}^{2} \mathrm{~s}^{-1} \mathrm{~V}^{-1}\right]}\end{array}$ & $\begin{array}{c}\text { Hydrated Ion Radius } \\
{[\mathrm{nm}]}\end{array}$ \\
\hline $\mathrm{H}^{+}$ & $3.76 \cdot 10^{-12}$ & $9.31 \cdot 10^{-9}$ & $3.63 \cdot 10^{-7}$ & 0.026 \\
$\mathrm{OH}-$ & $2.13 \cdot 10^{-12}$ & $5.38 \cdot 10^{-9}$ & $2.06 \cdot 10^{-7}$ & 0.464 \\
$\mathrm{Cl}$ & $8.20 \cdot 10^{-13}$ & $2.03 \cdot 10^{-9}$ & $7.91 \cdot 10^{-8}$ & $0.121 .0 .099,0.107$ \\
$\mathrm{Na}^{+}$ & $5.38 \cdot 10^{-13}$ & $1.33 \cdot 10^{-9}$ & $5.19 \cdot 10^{-8}$ & $0.184,0.186,0.164$ \\
$\mathrm{Ca}^{2+}$ & $3.20 \cdot 10^{-12}$ & $0.92 \cdot 10^{-9}$ & $6.18 \cdot 10^{-8}$ & $0.309,0.197,0.237$ \\
$\mathrm{HCO}_{3-}$ & $4.78 \cdot 10^{-12}$ & $1.18 \cdot 10^{-9}$ & $4.61 \cdot 10^{-8}$ & 0.207 \\
$\mathrm{CO}_{3}{ }^{--}$ & {$\left[1 / 2 \mathrm{CO}_{3}{ }^{2-}\right] 3.72 * 10^{-12}$} & $0.92 \cdot 10^{-9}$ & $7.18 \cdot 10^{-8}$ & 0.266 \\
\hline
\end{tabular}

Table 5 Cation and chloride rejection ( $20 \mathrm{mM} \mathrm{NaCl}, 1 \mathrm{mM} \mathrm{NaHCO} 3$ and $0.5 \mathrm{mM} \mathrm{CaCl}_{2}$, no organics).

\begin{tabular}{lccccccc}
\hline Membrane & $\mathrm{pH}$ & $\begin{array}{c}\mathrm{Jw}^{*} \\
{\left[\mathrm{Lm}^{2} \mathrm{~h}^{-1}\right]}\end{array}$ & $\begin{array}{c}\mathrm{Ca}^{2+} \\
\text { Rejection [\%] }\end{array}$ & $\begin{array}{c}\mathrm{Na}^{+} \\
\text {Rejection [\%] }\end{array}$ & $\begin{array}{c}\mathrm{Cl}^{2} \text { Rejection } \\
{[\%]}\end{array}$ & $\begin{array}{c}\mathrm{J} / \mathrm{Jw}_{0}{ }^{*} \\
{[-]}\end{array}$ & $\begin{array}{c}\text { Membrane } \\
\text { Zeta Potential } \\
{[\mathrm{mV}]}\end{array}$ \\
\hline TFC-ULP & 4.5 & 17.0 & $95 / 95 / 95$ & $90 / 88 / 87$ & $-/ 89$ & 0.49 & -9.4 \\
TFC-ULP & 8 & 16.4 & $96 / 95 / 94$ & $90 / 88 / 87$ & $90 / 89$ & 0.46 & -19.4 \\
TFC-ULP & 10 & 19.8 & $99 / 99 / 99$ & $86 / 95 / 96$ & $91 / 93$ & 0.46 & -18.5 \\
TFC-S & 4.5 & 53.2 & $96 / 95 / 96$ & $70 / 70 / 70$ & $27 / 72$ & 0.52 & +2.4 \\
TFC-S & 8 & 49.2 & $92 / 91 / 90$ & $72 / 70 / 95$ & $53 / 71$ & 0.55 & -6.5 \\
TFC-S & 10 & 45.1 & $94 / 89 / 88$ & $69 / 68 / 69$ & $50 / 70$ & 0.52 & -10.2 \\
TFC-SR & 4.5 & 39.8 & $95 / 95 / 95$ & $41 / 37 / 31$ & $45 / 43$ & 0.92 & -11.6 \\
TFC-SR & 8 & 45.2 & $61 / 67 / 70$ & $21 / 22 / 17$ & $27 / 25$ & 0.99 & -21.8 \\
TFC-SR & 10 & 40.2 & $78 / 80 / 94$ & $50 / 47 / 50$ & $63 / 49$ & 0.84 & -21.8 \\
CA-UF & 4.5 & 44.6 & $16 / 12 / 06$ & $13 / 08 / 04$ & $00 / 09$ & 1.02 & -2.3 \\
CA-UF & 8 & 46.9 & $11 / 01 / 01$ & $16 / 09 / 05$ & $19 / 15$ & 1.11 & -11.0 \\
CA-UF & 10 & 42.8 & $00 / 00 / 00$ & $14 / 09 / 08$ & $08 / 08$ & 1.03 & -11.0 \\
\hline
\end{tabular}

${ }^{1}$ Numbers in the first column are the result obtained from ion chromatography, while the second column values are the calculated rejection from $\mathrm{Na}$ and $\mathrm{Ca}$ results (neglecting the carbonate system, $\mathrm{H}^{+}$and $\mathrm{OH}-$ ). Both values are average values. * where Jwo: Initial Pure Water Flux; J: Flux
Table 6 Rejection as a function of salt composition (TFC-SR, $5 \mathrm{mg} \mathrm{L}^{-1} \mathrm{DOC} \mathrm{FA}$, pH 8).

\begin{tabular}{|c|c|c|c|c|c|}
\hline Solution Composition & $\begin{array}{c}\text { DOC } \\
\text { Rejection } \\
{[\%]}\end{array}$ & $\begin{array}{c}\mathrm{UV}_{254 \mathrm{~nm}} \\
\text { Rejection } \\
{[\%]}\end{array}$ & $\begin{array}{c}\mathrm{Ca}^{2+} \\
\text { Rejection } \\
{[\%]}\end{array}$ & $\begin{array}{c}\mathrm{Na}^{+} \\
\text {Rejection } \\
{[\%]}\end{array}$ & $\mathrm{J} / \mathrm{J}_{\mathrm{w}}$ \\
\hline $1 \mathrm{mM} \mathrm{NaHCO}_{3}$ & $90 / 93 / 96$ & $94 / 99 / 98$ & & $90 / 89 / 88$ & 0.96 \\
\hline $1 \mathrm{mM} \mathrm{NaHCO}_{3} ; 0.5 \mathrm{mM} \mathrm{CaCl}_{2}$ & $75 / 89 / 92$ & $94 / 97 / 97$ & $54 / 48 / 53$ & $19 / 08 / 06$ & 0.97 \\
\hline $1 \mathrm{mM} \mathrm{NaHCO}_{3} ; 1 \mathrm{mM} \mathrm{CaCl}_{2}$ & $87 / 94 / 95$ & $95 / 98 / 99$ & $48 / 46 / 62$ & $10 / 01 /-45$ & 0.78 \\
\hline $1 \mathrm{mM} \mathrm{NaHCO}_{3} ; 2.5 \mathrm{mM} \mathrm{CaCl}_{2}$ & $85 / 96 / 99$ & $98 / 99 / 99$ & $72 / 66 / 72$ & $-05 /-13 /-21$ & 0.85 \\
\hline $\begin{array}{l}1 \mathrm{mM} \mathrm{NaHCO} \\
\mathrm{mM} \mathrm{NaCl}\end{array}$ & $94 / 94 / 94$ & $94 / 96 / 98$ & $67 / 68 / 68$ & $34 / 40 / 38$ & 0.91 \\
\hline
\end{tabular}

Table 7 Rejection and flux ratio of membranes $\left(0.5 \mathrm{mM} \mathrm{CaCl}_{2}, 1 \mathrm{mM} \mathrm{NaHCO}_{3}, 20 \mathrm{mM} \mathrm{NaCl}\right.$, pH 8).

\begin{tabular}{|c|c|c|c|c|c|c|}
\hline Membrane & $\begin{array}{c}\text { IHSS FA } \\
\text { Concentration } \\
{[\mathrm{mg} / \mathrm{L} \text { DOC] }}\end{array}$ & $\begin{array}{c}\text { DOC } \\
\text { Rejection [\%] }\end{array}$ & $\begin{array}{c}\mathrm{UV}_{254 \mathrm{~nm}} \\
\text { Rejection [\%] }\end{array}$ & $\begin{array}{c}\mathrm{Ca} \\
\text { Rejection [\%] }\end{array}$ & $\begin{array}{c}\mathrm{Na} \\
\text { Rejection } \\
{[\%]}\end{array}$ & $\begin{array}{c}\mathrm{J} / \mathrm{J}_{\mathrm{W}} \\
0 \\
{[\%]} \\
\text { end }\end{array}$ \\
\hline TFC-ULP & 5 & $72 / 83 / 86$ & $80 / 91 / 93$ & $\begin{array}{l}87 / 92 / 92 \\
96 / 95 / 94\end{array}$ & & $\begin{array}{l}0.37 \\
0.46\end{array}$ \\
\hline TFC-S & $\begin{array}{l}5 \\
0\end{array}$ & $78 / 83 / 90$ & $93 / 95 / 96$ & $\begin{array}{l}92 / 95 / 96 \\
92 / 91 / 90\end{array}$ & $\begin{array}{l}74 / 85 / 87 \\
72 / 70 / 95\end{array}$ & $\begin{array}{l}0.63 \\
0.55\end{array}$ \\
\hline TFC-SR & $\begin{array}{l}5 \\
0\end{array}$ & 94 / 94 / 94 & $\begin{array}{c}94 / 96 / 98 \\
-\end{array}$ & $\begin{array}{l}67 / 68 / 68 \\
61 / 67 / 70\end{array}$ & $\begin{array}{l}34 / 40 / 38 \\
21 / 22 / 17\end{array}$ & $\begin{array}{l}0.91 \\
0.99\end{array}$ \\
\hline CA-UF & $\begin{array}{l}5 \\
0\end{array}$ & $\begin{array}{c}68 / 72 / 72 \\
-\end{array}$ & $\begin{array}{c}76 / 88 / 85 \\
-\end{array}$ & $\begin{array}{l}17 / 13 / 13 \\
11 / 01 / 01\end{array}$ & $\begin{array}{l}17 / 11 / 10 \\
16 / 09 / 05\end{array}$ & $\begin{array}{l}1.11 \\
1.11\end{array}$ \\
\hline
\end{tabular}




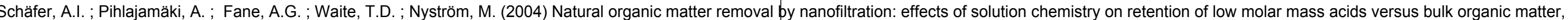
Journal of Membrane Science, 242, 1-2, 73-85. doi:10.1016/j.memsci.2004.05.018

Table 8 Rejection in the presence of different organic types for the TFC-SR membrane $(0.5 \mathrm{mM}$ $\left.\mathrm{CaCl}_{2}, 1 \mathrm{mM} \mathrm{NaHCO}, 20 \mathrm{mM} \mathrm{NaCl}\right)$.

\begin{tabular}{lccccc}
\hline Conditions & $\begin{array}{c}\text { DOC } \\
\text { Rejection [\%] }\end{array}$ & $\begin{array}{c}\mathrm{UV}_{254 n m} \\
\text { Rejection [\%] }\end{array}$ & $\begin{array}{c}\mathrm{Ca} \\
\text { Rejection [\%] }\end{array}$ & $\begin{array}{c}\mathrm{Na} \\
\text { Rejection }[\%]\end{array}$ & $\begin{array}{c}\mathrm{J} / \mathrm{J}_{\mathrm{W} 0} \\
{[-]}\end{array}$ \\
\hline FA pH 4.5 & $80 / 80 / 70$ & $99 / 98 / 96$ & $96 / 96 / 96$ & $46 / 36 / 22$ & 0.9 \\
FA pH 8 & $94 / 94 / 94$ & $94 / 96 / 98$ & $67 / 68 / 68$ & $34 / 40 / 38$ & 0.91 \\
FA pH 10 & $88 / 93 / 94$ & $94 / 97 / 99$ & $72 / 65 / 62$ & $37 / 30 / 21$ & 0.9 \\
$\mathrm{HA} \mathrm{pH} \mathrm{4.5}$ & $66 / 71 / 80$ & $97 / 99 / 98$ & $86 / 91 / 92$ & $50 / 48 / 49$ & 0.8 \\
$\mathrm{HA} \mathrm{pH} \mathrm{8}$ & $72 / 72 / 78$ & $96 / 98 / 98$ & $66 / 58 / 64$ & $28 / 10 / 20$ & 0.93 \\
HA pH 10 & $71 / 69 / 73$ & $97 / 98 / 99$ & $81 / 76 / 76$ & $55 / 53 / 51$ & 0.82 \\
NOM pH 4.5 & $66 / 70 / 72$ & $94 / 95 / 97$ & $91 / 93 / 93$ & $49 / 53 / 52$ & 0.8 \\
NOM pH 8 & $66 / 71 / 70$ & $96 / 97 / 97$ & $74 / 74 / 74$ & $39 / 40 / 40$ & 0.9 \\
NOM pH 10 & $74 / 83 / 84$ & $64 / 87 / 91$ & $72 / 77 / 73$ & $45 / 58 / 52$ & 0.74 \\
\hline
\end{tabular}

Table 9 Effect of IHSS HA concentration on rejection ( $\mathrm{pH} 8$, TFC-SR, $0.5 \mathrm{mM} \mathrm{CaCl}_{2}, 1 \mathrm{mM}$ $\mathrm{NaHCO}_{3}, 20 \mathrm{mM} \mathrm{NaCl}$ )

\begin{tabular}{cccccc}
\hline $\begin{array}{c}\text { HA Concentration } \\
{\left[\mathrm{mgL}^{-1} \mathrm{DOC}\right]}\end{array}$ & $\begin{array}{c}\text { DOC Rejection } \\
{[\%]}\end{array}$ & $\begin{array}{c}\mathrm{UV}_{254 m m} \\
\text { Rejection }[\%]\end{array}$ & $\begin{array}{c}\mathrm{Ca} \\
\text { Rejection }[\%]\end{array}$ & $\begin{array}{c}\mathrm{Na} \\
\text { Rejection }[\%]\end{array}$ & $\begin{array}{c}\mathrm{J} / \mathrm{J}_{\mathrm{W} 0} \\
{[-]}\end{array}$ \\
\hline 2.5 & $58 / 91 / 94$ & $96 / 98 / 99$ & $57 / 52 / 56$ & $19 / 10 / 13$ & 0.85 \\
5.0 & $72 / 72 / 78$ & $96 / 98 / 98$ & $66 / 58 / 64$ & $28 / 10 / 20$ & 0.93 \\
7.5 & $78 / 91 / 95$ & $99 / 98 / 98$ & $66 / 67 / 68$ & $24 / 21 / 23$ & 0.96 \\
\hline
\end{tabular}

\section{FIGURES}

Figure 1 Membrane surface potential as a function of solution composition (A) TFC-SR, (B) TFC-S, (C) TFC-ULP, and (D) CA-UF.

Figure 2 Membrane surface zeta potential measured in background solution $(10 \mathrm{mM} \mathrm{NaCl}, 0.5$ $\mathrm{mM} \mathrm{CaCl}_{2}$, and $1 \mathrm{mM} \mathrm{NaHCO} 3$.

Figure 3 Transmission of FA through membranes as a function of calcium concentration (TFC-SR, $5 \mathrm{mg} / \mathrm{L}$ as DOC IHSS FA, $1 \mathrm{mM} \mathrm{NaHCO}$

Figure 4 Rejection of sodium as a function of calcium concentration (TFC-SR, $5 \mathrm{mg} / \mathrm{L}$ as DOC IHSS FA, $1 \mathrm{mM} \mathrm{NaHCO}$, other ions as indicated)

Figure 5 LC-OCD analysis of NOM feed and permeate of TFC-S membrane.

Figure 6 LC-OCD analysis of $\mathrm{HA}$ as a function of $\mathrm{pH}$ for TFC-S membrane.

Figure 7 Effect of stirring on DOC and cation rejection (TFC-S membrane, $\mathrm{pH} 8,0.5 \mathrm{mM} \mathrm{CaCl}_{2}$, $1 \mathrm{mM} \mathrm{NaHCO} 3,20 \mathrm{mM} \mathrm{NaCl}$ ). 


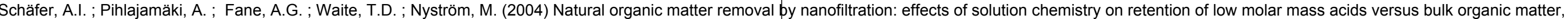
Journal of Membrane Science, 242, 1-2, 73-85. doi:10.1016/j.memsci.2004.05.018

FIG 1
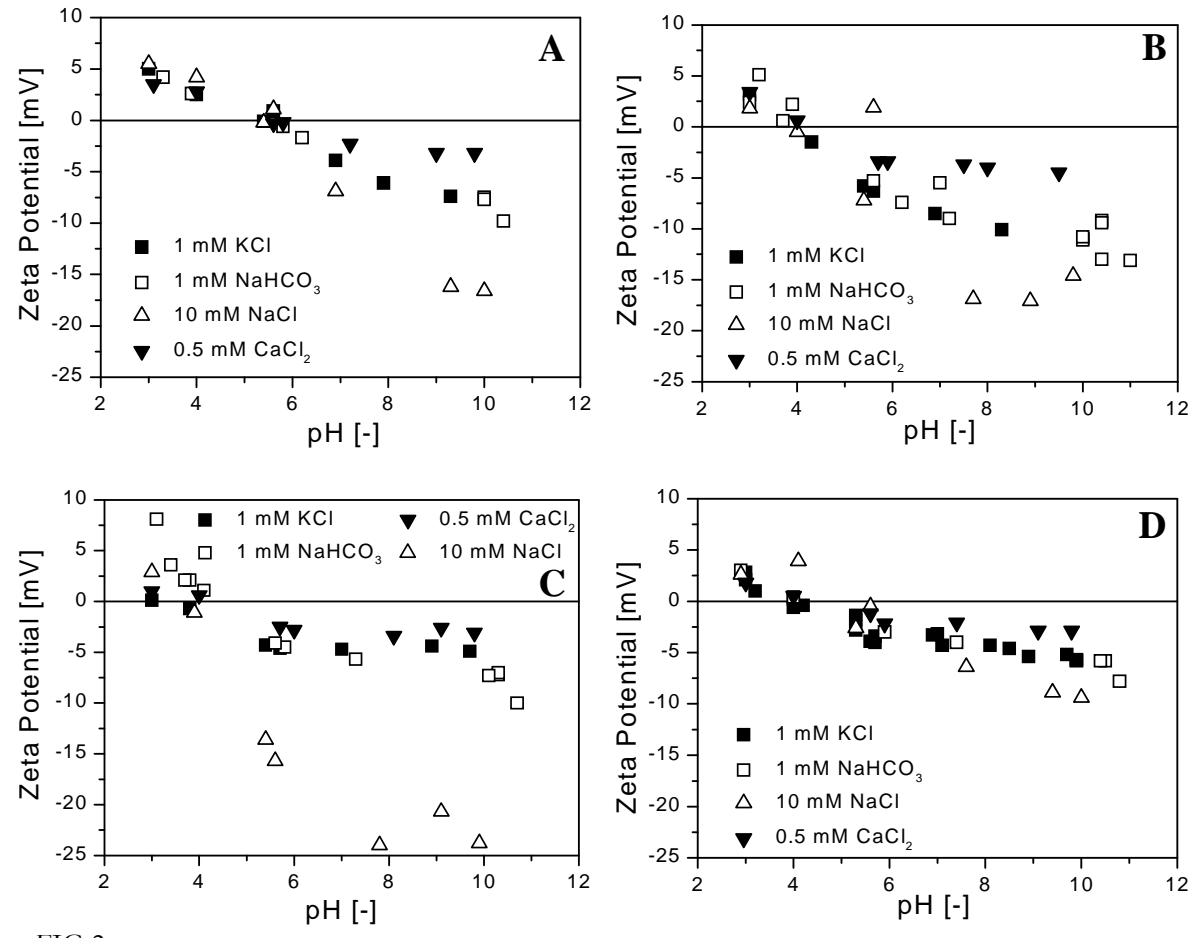

FIG 2

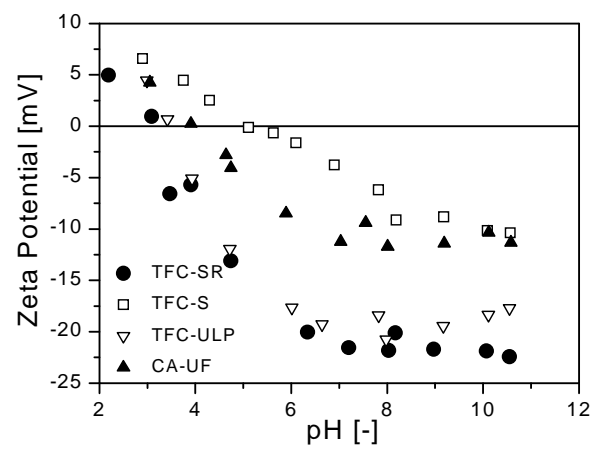

FIG 3

FIG 4
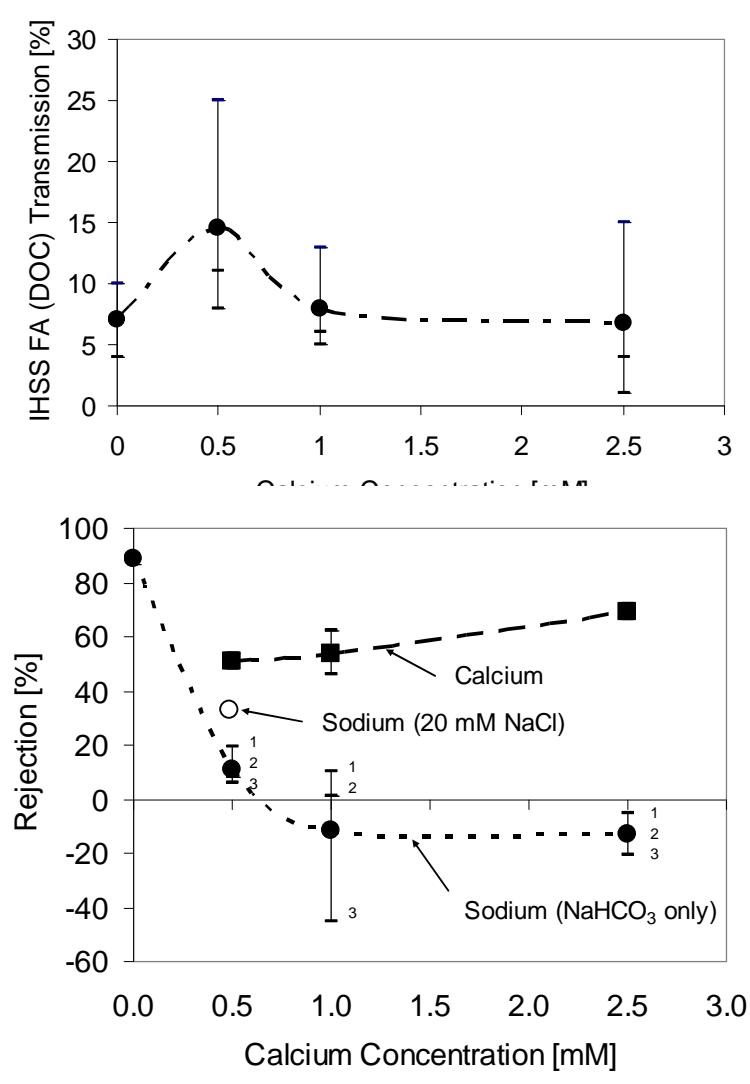


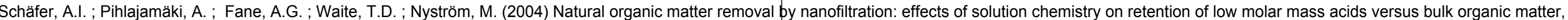
Journal of Membrane Science, 242, 1-2, 73-85. doi:10.1016/j.memsci.2004.05.018

FIG 5

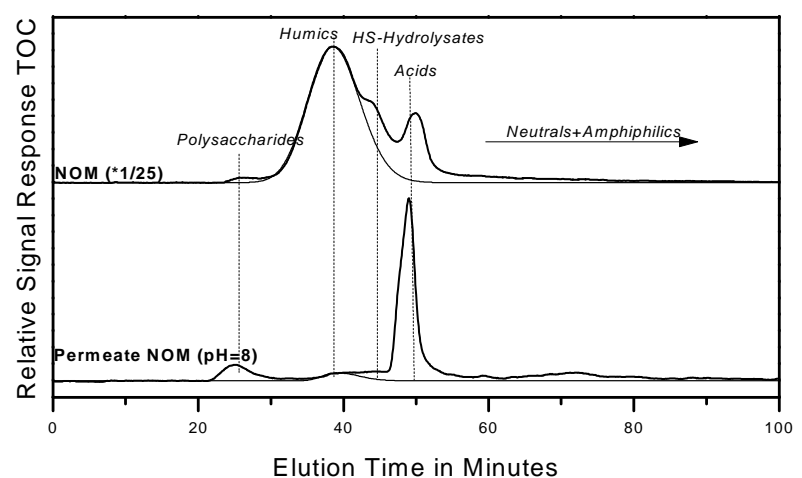

FIG 6

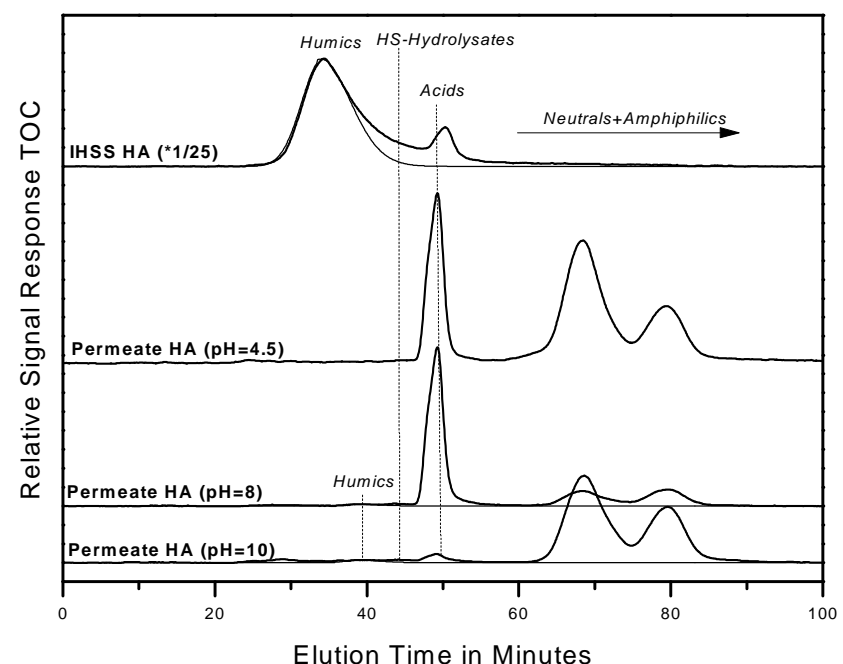

FIG 7

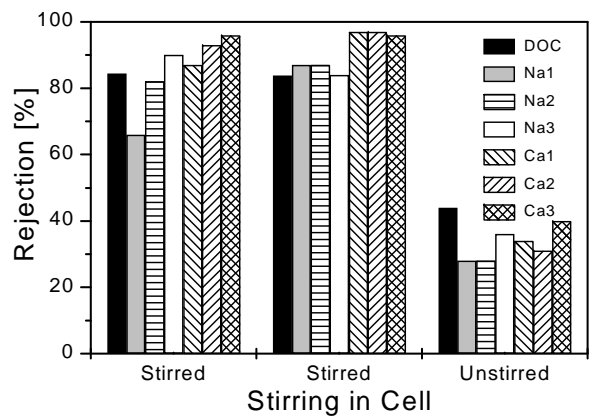

